\title{
Analisis Faktor Pemberian ASI Eksklusif pada Ibu Bekerja di Instansi Pemerintah
}

\author{
Fitriana Noor Khayati ${ }^{*}$, Puput Risti Kusumaningrum² \\ ${ }^{1}$ STIKES Muhammadiyah Klaten, Jl. Ir. Soekarno Km.1 Buntalan Klaten Tengah, Klaten \\ ${ }^{2}$ STIKES Muhammadiyah Klaten, Jl. Ir. Soekarno Km.1 Buntalan Klaten Tengah, Klaten \\ *E-mail: fnoorkhayati@gmail.com \\ doi : https://doi.org/10.30787/gaster.v17i2.410 \\ Received: Mei 2019 | Revised: Mei 2019 | Accepted: Agustus 2019
}

\begin{abstract}
ABSTRAK
Latar Belakang: Air Susu Ibu (ASI) merupakan makanan terbaik yang mengandung semua unsur zat gizi yang dibutuhkan bayi usia 0-6 bulan. Keberhasilan pemberian ASI eksklusif dipengaruhi oleh banyak hal. Tujuan: Penelitian ini bertujuan untuk untuk mengetahui determinan yang mempengaruhi pemberian ASI eksklusif pada ibu bekerja. Metodologi: Desain penelitian ini merupakan jenis penelitian kuantitatif dengan pendekatan cross sectional. Populasi pada penelitian ini adalah ibu yang memiliki anak usia balita dan bekerja di instansi pemerintah Kabupaten Klaten. Teknik pengambilan sampel pada penelitian ini adalah teknik non probability sampling dengan pendekatan accidental sampling sebanyak 39 responden. Instrumen yang digunakan berupa kuesioner dan panduan observasi ruang laktasi. Data dianalisa dengan analisa univariat distribusi frekuensi, analisa bivariat Koefisien kontingensi dan analisa multivariate Regresi Logistik dengan nilai signifikansi 95\%. Hasil: Sebagian besar ibu bekerja (58,3\%) melakukan praktik pemberian ASI eksklusif. Tidak ada hubungan antara karakter sosiodemografik dengan praktik pemberian ASI eksklusif, faktor pre dan post natal yang mempengaruhi praktik pemberian ASI eksklusif adalah ANC dengan p value 0,012, faktor psikososial yang memiliki hubungan signifikan dengan praktik pemberian ASI antara lain pemberian susu formula di pelayanan kesehatan (p value 0,003), pemberian MPASI saat usia kurang dari 6 bulan (p value 0,032), keyakinan ibu ( $p$ value 0,000) serta antenatal care paling besar pengaruhnya terhadap praktik pemberian ASI secara eksklusif. Kesimpulan: Faktor antenatal care paling berpengaruh terhadap praktik pemberian ASI eksklusif.
\end{abstract}

Kata kunci: ASI eksklusif; ibu bekerja; instansi pemerintah

\section{ABSTRACT}

Background: Mother's milk (ASI) is the best food that contains all the nutrients needed by babies aged 0-6 months. The success of exclusive breastfeeding is influenced by many things. Objective: This study aims to determine the determinants that influence exclusive breastfeeding for working mothers. Methodology: The design of this study is a type of quantitative research with a cross sectional approach. The population in this study are mothers who have children 
aged under five and work in government agencies in Klaten Regency. The sampling technique in this study was a non probability sampling technique with an accidental sampling approach of 39 respondents. The instrument used was a questionnaire and a lactation chamber observation guide. Data were analyzed by univariate frequency distribution analysis, bivariate analysis Contingency coefficient and multivariate logistic regression analysis with a significance value of 95\%. Results: Most working mothers (58.3\%) practice exclusive breastfeeding. There is no relationship between sociodemographic characters and exclusive breastfeeding practices, the pre and post natal factors that influence the practice of exclusive breastfeeding are ANC with $p$ value 0.012, psychosocial factors that have a significant relationship with the practice of breastfeeding, including formula feeding in health services ( $p$ value 0.003), giving MPASI at less than 6 months of age ( $p$ value 0.032), maternal beliefs ( $p$ value 0,000) and antenatal care have the greatest influence on the practice of exclusive breastfeeding. Conclusion: The most influential antenatal care factor for exclusive breastfeeding practices .

Keywords: Exclusive breastfeeding; working mothers; government agencies.

\section{PENDAHULUAN}

ASI merupakan nutrisi yang dibutuhkan oleh bayi umur 0-6 bulan. World Health Organization (WHO, 2003) merekomendasikan pemberian Air Susu Ibu (ASI) secara eksklusif selama enam bulan pertama kehidupan dan dilanjutkan pemberian ASI serta makanan pendamping hingga usia dua tahun atau lebih.

Praktik pemberian ASI eksklusif di Indonesia masih relative rendah. Hasil Riskesdas (2013) menunjukkan bahwa persentase pola menyusui pada bayi umur 0 bulan adalah $39,8 \%$ dan menurun hingga umur 5 bulan yaitu sebesar 15,3\%. Cakupan pemberian ASI eksklusif di Indonesia sebesar 54,3\% sedangkan Provinsi Jawa Tengah memiliki cakupan sebesar 58,4\%.
Data juga menunjukkan bahwa Provinsi Jawa Tengah memiliki cakupan pemberian makanan prelakteal relatif lebih tinggi daripada cakupan secara nasional yaitu 44,5\%. Cakupan pemberian susu formula di Jawa Tengah merupakan peringkat keenam.

Pemerintah telah menetapkan beberapa kebijakan untuk meningkatkan cakupan pemberian ASI eksklusif di Indonesia. Peraturan Pemerintah Nomor 33 Tahun 2012 menginstruksikan kepada pemerintah daerah dan swasta untuk bekerjasama mendukung pemberian ASI eksklusif dan Inisiasi Menyusui Dini (IMD). Melalui Peraturan Pemerintah ini, pemerintah memformalkan hak perempuan untuk menyusui (termasuk di tempat kerja) dan melarang promosi pengganti ASI. 
Pemberian ASI eksklusif dan IMD bertujuan untuk memenuhi kebutuhan nutrisi bayi dan mencegah kekurangan gizi pada balita (Kemenkes, 2013).

Keberhasilan pemberian ASI eksklusif dipengaruhi oleh banyak hal. Penelitian Kurniawan (2013) menunjukkan bahwa faktor yang menghalangi keberhasilan pemberian ASI eksklusif antara lain permasalahan menyusui, kunjungan ke klinik laktasi dan keinginan, keyakinan ibu, persepsi ibu tentang kepuasan bayi saat menyusu, dukungan suami dan orang tua, usia ibu, ibu bekerja, pemberian susu formula di instansi pelayanan keshatan, MPASI dini pada bayi usia $<6$ bulan serta pemakaian empeng. Hasil penelitian Nkrumah (2017) menunjukkan bahwa ibu yang bekerja dalam sektor formal lebih sedikit (16\%) melakukan pemberian ASI eksklusif dibandingkan dengan ibu yang bekerja dalam sektor informal (84\%).

Bekerja merupakan salah satu kondisi dimana ibu harus terpisah dari bayinya. Ibu harus meninggalkan rumah ketika cutinya habis dimana kurang dari 6 bulan. Hal ini dibutuhkan upaya dan dukungan bagi ibu bekerja untuk dapat terus memberikan ASI eksklusif.
Rendahnya pemberian ASI eksklusif dipengaruhi oleh gencarnya promosi susu formula, ibu harus kembali bekerja, kurangnya kesadaran dan pengetahuan ibu tentang ASI (Prasetyono, 2012). Selain itu ASI belum keluar pada hari pertama sehingga bayi dianggap perlu diberikan minuman lain, payudara terlalu kecil sehingga dianggap kurang menghasilkan ASI padahal ukuran payudara tidak menentukan apakah produksi ASI cukup atau kurang (Kristiyanasari, 2009). Ibu yang memilih untuk memberikan ASI eksklusif merupakan langkah yang tepat. Banyak hal yang positif yang dapat dirasakan oleh bayi dan ibu. Bayi yang diberi susu formula sangat rentan terserang penyakit seperti infeksi saluran pencernaan, infeksi saluran pernafasan, meningkatkan resiko alergi, meningkatkan resiko serangan asma, menurunkan perkembangan kecerdasan kognitif, meningkatkan resiko kegemukan, risiko penyakit jantung dan pembuluh darah, resiko diabetes mellitus, resiko penyakit menahun (Roesli, 2008).

Kabupaten Klaten sebagai salah satu kabupaten di Provinsi Jawa Tengah telah mengatur tentang ASI eksklusif melalui Peraturan Daerah Kabupaten Klaten Nomor 7 
Tahun 2008. Berdasarkan peraturan tersebut, tempat-tempat umum dan perkantoran/ instansi, baik milik pemerintah maupun swasta wajib menyediakan ruang laktasi guna mendukung keberhasilan pelaksanaan ASI eksklusif. Kebijakan ini diharapkan dapat memberikan perlindungan secara hukum dan kesempatan bagi ibu untuk memberikan ASI ekpada bayinya dimanapun berada. Namun masih banyak instansi pemerintah maupun swasta yang belum menyediakan ruang laktasi yang nyaman bagi ibu bekerja. Penelitian ini bertujuan untuk mengetahui determinan pemberian ASI eksklusif pada ibu bekerja d Kabupaten Klaten.

\section{METODE DAN BAHAN}

Penelitian ini merupakan jenis penelitian kuantitatif dengan pendekatan cross sectional. Populasi dalam penelitian ini adalah semua ibu menyusui yang bekerja di instansi pemerintah Kabupaten Klaten. Sampel pada penelitian ini adalah ibu yang memiliki anak usia balita dan bekerja di instansi pemerintah Kabupaten Klaten. Teknik pengambilan sampel pada penelitian ini adalah teknik non probability sampling dengan pendekatan accidental sampling. Besar sampel yang digunakan sebanyak 39 orang. Adapun data yang akan digunakan dalam penelitian ini adalah praktik pemberian ASI eksklusif dan faktor-faktor yang mempengaruhi pemberian ASI eksklusif (faktor sosiodemografi, faktor pre/post natal dan faktor psikososial). Metode pengumpulan data yang dilakukan adalah dengan membagikan kuesioner dan observasi tempat bekerja. Data dianalisa dengan analisa univariat distribusi frekuensi, analisa bivariat Koefisien kontingensi dan analisa multivariate Regresi Logistik dengan nilai signifikansi $95 \%$.

\section{HASIL DAN PEMBAHASAN}

Tabel 1. Distribusi Frekuensi Praktik Pemberian ASI Eksklusif

\begin{tabular}{|c|c|c|c|}
\hline No. & Variabel & f & $\%$ \\
\hline \multirow[t]{3}{*}{1} & ASI Eksklusif & & \\
\hline & Tidak & 15 & 41.7 \\
\hline & $\mathrm{Ya}$ & 21 & 58.3 \\
\hline \multirow[t]{3}{*}{2} & $\begin{array}{l}\text { Frekuensi Memerah ASI } \\
\text { per hari }\end{array}$ & & \\
\hline & $<8$ kali & 6 & 16.7 \\
\hline & 8 kali atau lebih & 30 & 83.3 \\
\hline \multirow[t]{4}{*}{3} & Memerah ASI di kantor & & \\
\hline & Tidak & 7 & 19.4 \\
\hline & Iya & 29 & 80.6 \\
\hline & Total & 36 & 100 \\
\hline
\end{tabular}

Tabel 1 menunjukkan bahwa sebagian besar ibu melakukan praktik pemberian asi eksklusif yaitu sebanyak 21 orang $(58,3 \%)$, 
memerah ASI per hari sebanyak 8 kali atau lebih serta memerah ASI di kantor.

Tabel 2. Distribusi Frekuensi Fasilitas Laktasi

\begin{tabular}{lcccc}
\hline \multicolumn{1}{c}{ Parameter } & \multicolumn{2}{c}{ Ya } & \multicolumn{2}{c}{ Tidak } \\
& N & \% & N & \% \\
\hline $\begin{array}{l}\text { Terdapat ruang laktasi } \\
\text { khusus }\end{array}$ & 8 & 47,1 & 9 & 52,9 \\
Sirkulasi udara baik & 15 & 88,2 & 2 & 11,8 \\
Pencahayaan baik & 16 & 94,1 & 1 & 5,9 \\
Suhu ruangan sejuk & 16 & 94,1 & 1 & 5,9 \\
Terdapat kursi & 14 & 82,3 & 3 & 17,6 \\
Terdapat meja & 12 & 70,6 & 5 & 29,4 \\
Ruangan bersih & 17 & 100 & 0 & 0 \\
Terdapat tempat cuci & 11 & 64,7 & 6 & 35,3 \\
tangan & & & & \\
Terdapat sterilisator & 2 & 11,8 & 15 & 88,2 \\
Terdapat kulkas & 15 & 88,2 & 2 & 11,8 \\
\hline
\end{tabular}

Tabel 2 menunjukkan bahwa 9 kantor $(52,9 \%)$ tidak memiliki ruang laktasi khusus. Berdasarkan data dari responden didapat bahwa ruang laktasi biasanya menggunakan salah satu ruangan yang tidak dipakai. Sebagian besar memliki sirkulasi udara, pencahayaan yang baik, suhu ruangan sejuk, terdapat kursi dan meja, bersih, terdapat kulkas. Namun di ruangan tersebut tidak ada sterilisator dan tempat cuci tangan tersedia secara terpisah.

Tabel 3 menunjukkan hubungan antara karakter sosiodemografik dengan pemberian ASI eksklusif. Berdasarkan tabel tersebut dapat dilihat bahwa tidak ada hubungan antara karakter sosiodemografik dengan praktik pemberian ASI eksklusif.

Tabel 3. H ubungan k a rakterist i k sosiodemografik dengan pemberian ASI eksklusif pada ibu bekerja $(\mathrm{n}=36)$

\begin{tabular}{|c|c|c|c|c|c|}
\hline \multirow[t]{2}{*}{ No. } & \multirow[t]{2}{*}{ Variabel } & \multicolumn{3}{|c|}{$\begin{array}{c}\text { Pemberian ASI } \\
\text { Eksklusif }\end{array}$} & \multirow[t]{2}{*}{ p value } \\
\hline & & Tidak & Ya & Total & \\
\hline \multirow[t]{5}{*}{1} & Usia Ibu & & & & 0,310 \\
\hline & $20-25$ tahun & 1 & 1 & 2 & \\
\hline & 26-30 tahun & 2 & 6 & 8 & \\
\hline & 31-35 tahun & 5 & 10 & 15 & \\
\hline & $\begin{array}{l}36 \text { tahun atau } \\
\text { lebih }\end{array}$ & 7 & 4 & 11 & \\
\hline \multirow[t]{5}{*}{2} & Usia Bayi & & & & 0,769 \\
\hline & $7-12$ bulan & 7 & 8 & 15 & \\
\hline & 13-24 bulan & 4 & 8 & 12 & \\
\hline & $25-36$ bulan & 0 & 0 & 0 & \\
\hline & $37-60$ bulan & 4 & 5 & 9 & \\
\hline \multirow[t]{5}{*}{3} & \multicolumn{4}{|c|}{ Jarak Rumah ke Kantor } & 0,548 \\
\hline & $1 / 4-1 / 2 \mathrm{~km}$ & 0 & 1 & 1 & \\
\hline & $1 / 2-1 \mathrm{~km}$ & 0 & 1 & 1 & \\
\hline & $1-2 \mathrm{~km}$ & 3 & 2 & 5 & \\
\hline & $>2 \mathrm{~km}$ & 12 & 17 & 29 & \\
\hline \multirow[t]{3}{*}{4} & \multicolumn{4}{|c|}{ Transportasi ke tempat kerja } & 0,151 \\
\hline & motor pribadi & 12 & 20 & 32 & \\
\hline & mobil pribadi & 3 & 1 & 4 & \\
\hline \multirow[t]{5}{*}{5} & Pendidikan Ibu & & & & 0,05 \\
\hline & SMA/ sederajat & 1 & 0 & 1 & \\
\hline & DIII & 2 & 11 & 13 & \\
\hline & Sarjana & 7 & 8 & 15 & \\
\hline & Pascasarjana & 5 & 2 & 7 & \\
\hline \multirow[t]{5}{*}{6} & $\begin{array}{l}\text { Pendidikan } \\
\text { Suami }\end{array}$ & & & & 0,686 \\
\hline & SMA/ sederajat & 3 & 5 & 8 & \\
\hline & DIII & 3 & 4 & 7 & \\
\hline & Sarjana & 8 & 12 & 20 & \\
\hline & Pascasarjana & 1 & 0 & 1 & \\
\hline \multirow[t]{2}{*}{7} & $\begin{array}{l}\text { Lama Cuti } \\
\text { Melahirkan }\end{array}$ & & & & 0,76 \\
\hline & $<3$ bulan & 5 & 6 & 11 & \\
\hline
\end{tabular}




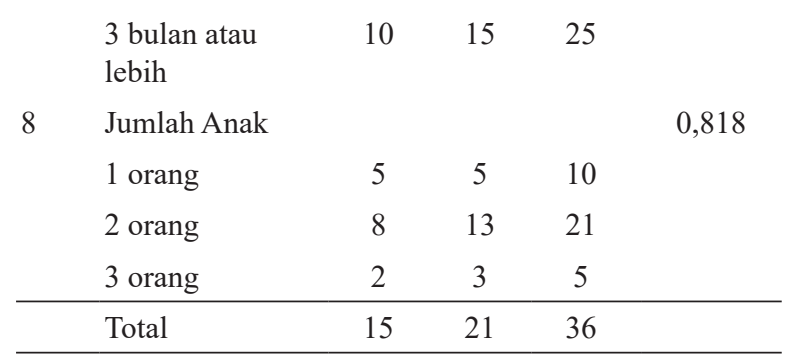

*Uji Koefisien Kontingensi

Hasil penelitian ini menunjukkan bahwa tidak ada hubungan antara karakteristik sosiodemografi (usia ibu, usia bayi, jarak rumah, transportasi ke tempat kerja, pendidikan ibu, pendidikan suami, lama cuti melahirkan, lama jam kerja per hari dan jumlah anak) dengan pemberian ASI eksklusif pada ibu bekerja. Hal ini berbeda dengan hasil penelitian lain yang menunjukkan bahwa faktor usia berhubungan dengan praktik pemberian ASI eksklusif (Kurniawan, 2013). Penelitian Astuti (2013) juga menunjukkan bahwa ada hubungan yang signifikan antara pendidikan ibu, pekerjaan ibu dengan pemberian ASI eksklusif.

Hasil penelitian ini dimungkinkan dikarenakan sebagian besar responden memiliki pendidikan tinggi (minimal DIII) hal ini memungkinkan penerimaan informasi tentang ASI eksklusif lebih baik pada responden. Jarak rumah ke tempat kerja juga tidak mempengaruhi pemberian ASI eksklusif.
Hasil penelitian ini sebanyak 17 responden memiliki jarak rumah ke kantor lebih dari 2 kilometer dan tetap memberikan ASI eksklusif. Berdasarkan wawancara, responden mengatakan bahwa responden tetap dapat memerah ASI selama bekerja.

Berdasarkan Tabel 4 dapat dilihat bahwa faktor pre dan post natal yang mempengaruhi praktik pemberian ASI eksklusif adalah ANC dengan $\mathrm{p}$ value 0,012 . Hasil penelitian menunjukkan bahwa ada satu faktor pre natal yang berhubungan dengan pemberian ASI eksklusif pada ibu bekerja yaitu faktor Antenatal Care. Sebanyak 21 ibu melakukan antenatal care dengan dokter dan melakukan pemberian ASI secara eksklusif. Perawatan antenatal merupakan pendukung keberhasilan pemberian ASI eksklusif. Hal ini sesuai dengan rekomendasi dari WHO (2017) bahwa salah satu keberhasilan dalam ASI eksklusif adalah dengan membuat lingkungan yang mendukung diantaranya dapat dilakukan dengan fasilitas pelayanan ibu dan anak harus membuat kebijakan tertulis tentang menyusui dan dikomunikasikan kepada staf dan orang tua, staf harus memiliki pengetahuan, kompetensi dan keterampilan yang baik untuk mendukung ibu menyusui, ibu hamil dan keluarganya diberi 
konseling tentang manfaat dan manajemen menyusui serta perencanaan pulang yang dikoordiasikan sehingga orang tua danbayi mendapat dukungan berkelanjutan dan pelayanan yang sesuai.

Faktor pre dan post natal yang lain (penyuluhan ASI esklusif, pengalaman laktasi sebelumnya, jenis persalinan, tempat persalinan, penolong persalinan, inisiasi menyusui dini dan rawat gabung) tidak memiliki hubungan yang signifikan dengan praktik pemberian ASI eksklusif pada ibu bekerja. Penelitian Suan, dkk (2017) dengan desain kualitatif kepada sepuluh pekerja perawatan anak di Malaysia menunjukkan bahwa semua partisipan memiliki sikap positif dalam mendukung praktik pemberian ASI eksklusif. Berbagai dukungan yang dilakukan antara lain melabeli botol ASI, mengijinkan ibu untuk istirahat dan memberikan materi bacaan.

Tabel 4. Hubungan faktor pre/post natal dengan pemberian ASI eksklusif $(\mathrm{n}=36)$

\begin{tabular}{|c|c|c|c|c|c|}
\hline \multirow[t]{2}{*}{ No. } & \multirow[t]{2}{*}{ Variabel } & \multicolumn{3}{|c|}{$\begin{array}{c}\text { Pemberian ASI } \\
\text { Eksklusif }\end{array}$} & \multirow{2}{*}{$\underset{\text { value }}{\mathrm{p}}$} \\
\hline & & Tidak & Ya & Total & \\
\hline \multirow[t]{3}{*}{1} & $\begin{array}{l}\text { Penyuluhan ASI } \\
\text { eksklusif }\end{array}$ & & & & 0,364 \\
\hline & belum pernah & 8 & 8 & 16 & \\
\hline & sudah pernah & 7 & 13 & 20 & \\
\hline
\end{tabular}

\begin{tabular}{|c|c|c|c|c|c|}
\hline \multirow[t]{2}{*}{ No. } & \multirow[t]{2}{*}{ Variabel } & \multicolumn{3}{|c|}{$\begin{array}{c}\text { Pemberian ASI } \\
\text { Eksklusif }\end{array}$} & \multirow{2}{*}{$\begin{array}{c}\mathrm{p} \\
\text { value }\end{array}$} \\
\hline & & Tidak & Ya & Total & \\
\hline \multirow[t]{3}{*}{2} & $\begin{array}{l}\text { Pengalaman Laktasi } \\
\text { Sebelumnya }\end{array}$ & & & & 0,355 \\
\hline & $\begin{array}{l}\text { belum pernah } \\
\text { menyusui }\end{array}$ & 4 & 3 & 7 & \\
\hline & pernah menyusui & 11 & 18 & 29 & \\
\hline \multirow[t]{3}{*}{3} & ANC & & & & 0,012 \\
\hline & Dokter & 11 & 21 & 32 & \\
\hline & Bidan & 4 & 0 & 4 & \\
\hline \multirow[t]{3}{*}{4} & Jenis Persalinan & & & & 0,473 \\
\hline & $\begin{array}{l}\text { pervaginam } \\
\text { (spontan) }\end{array}$ & 11 & 13 & 24 & \\
\hline & operasi SC & 4 & 8 & 12 & \\
\hline \multirow[t]{3}{*}{5} & Tempat Persalinan & & & & 0,935 \\
\hline & rumah sakit & 13 & 18 & 31 & \\
\hline & klinik bersalin & 2 & 3 & 5 & \\
\hline \multirow[t]{3}{*}{6} & Penolong Persalinan & & & & 0,355 \\
\hline & Dokter & 11 & 18 & 29 & \\
\hline & Bidan & 4 & 3 & 7 & \\
\hline \multirow[t]{3}{*}{7} & IMD & & & & 0,65 \\
\hline & Tidak & 3 & 3 & 6 & \\
\hline & Iya & 12 & 18 & 30 & \\
\hline \multirow[t]{4}{*}{8} & Rawat Gabung & & & & 0,174 \\
\hline & Tidak & 4 & 2 & 6 & \\
\hline & Ya & 11 & 19 & 30 & \\
\hline & Total & 15 & 21 & 36 & \\
\hline
\end{tabular}

*Uji Koefisien Kontingensi

Tabel 5. menunjukkan hubungan antara faktor psikososial dengan praktik pemberian ASI eksklusif. Tabel 5. menunjukkan bahwa faktor psikososial yang memiliki hubungan signifikan dengan praktik pemberian ASI antara lain pemberian susu formula di pelayanan kesehatan ( $\mathrm{p}$ value 0,003$)$, pemberian MPASI saat usia kurang dari 6 bulan (p value 0,032 ), keyakinan ibu (p value $<0,001)$. 
ISSN: 1858-3385, EISSN: 2549-7006

GASTER Vol. 17 No. 2 Agustus 2019

Tabel 5. Hubungan antara faktor psikososial dengan praktik pemberian ASI eksklusif $(n=36)$

\begin{tabular}{ccc}
\hline & \multicolumn{2}{c}{$\begin{array}{c}\text { Pemberian ASI } \\
\text { No. }\end{array}$} \\
\cline { 2 - 3 } & $\begin{array}{c}\mathbf{p} \\
\text { value }\end{array}$ \\
\cline { 2 - 3 } & Tidak Ya Total & \\
\hline
\end{tabular}

1 Diberi Susu Formula

di Pelayanan

Kesehatan

Ya

Tidak

$\begin{array}{lll}7 & 1 & 8\end{array}$

0,003

Permasalahan

Menyusui

Ya

$\begin{array}{lll}8 & 20 & 28\end{array}$

Tidak

3 MPASI Usia kurang dari 6 bulan

Tidak

Ya

4 Memakai empeng

Tidak

Ya

5 Keinginan Ibu

Memberikan ASI

eksklusif

Tidak

Ya

6 Keyakinan Ibu

kurang yakin

sangat yakin

7 Persepsi kepuasan bayi

Tidak

Ya

8 Dukungan Suami kurang mendukung $\quad 1 \quad 0$ $\begin{array}{llll}\text { sangat mendukung } & 14 & 21 & 35\end{array}$

9 Dukungan orang terdekat

kurang mendukung sangat mendukung

10 Dukungan Instansi Tempat Bekerja

kurang mendukung sangat mendukung

\begin{tabular}{|c|c|c|c|c|c|}
\hline \multirow{2}{*}{ No. } & \multirow{2}{*}{ Variabel } & \multicolumn{3}{|c|}{$\begin{array}{c}\text { Pemberian ASI } \\
\text { Eksklusif }\end{array}$} & \multirow{2}{*}{$\begin{array}{c}\mathrm{p} \\
\text { value }\end{array}$} \\
\hline & & Tidak & Ya & Total & \\
\hline \multirow[t]{4}{*}{11} & $\begin{array}{l}\text { Ruang Laktasi di } \\
\text { Tempat Kerja }\end{array}$ & & & & \\
\hline & tidak ada & 9 & 6 & 15 & 0,127 \\
\hline & $\begin{array}{l}\text { ada namun kurang } \\
\text { lengkap/nyaman }\end{array}$ & 4 & 7 & 11 & \\
\hline & ada lengkap/nyaman & 2 & 8 & 10 & \\
\hline \multirow[t]{4}{*}{12} & $\begin{array}{l}\text { Kelonggaran Waktu } \\
\text { Memerah ASI }\end{array}$ & & & & \\
\hline & Tidak & 1 & 1 & 2 & 0,806 \\
\hline & Ya & 14 & 20 & 34 & \\
\hline & Total & 15 & 21 & 36 & \\
\hline
\end{tabular}

*Uji Koefisien Kontingensi

Hasil penelitian menunjukkan bahwa ada beberapa faktor psikososial yaitu diberi susu formula di pelayanan kesehatan, pemberian MPASI kurang dari enam bulan dan keyakinan ibu berhubungan secara signifikan dengan pemberian ASI eksklusif pada ibu bekerja. Adapun faktor psikososial yang lain tidak berhubungan secara signifikan dengan pemberian ASI secara eksklusif pada ibu bekerja, yaitu permasalahan menyusui, pemakaian empeng, keinginan ibu menyusui, persepsi kepuasan menyusu, dukungan suami, dukungan orang terdekat, dukungan instansi tempat bekerja, ruang laktasi di tempat kerja dan kelonggaran waktu memerah ASI. Hasil penelitian didukung juga oleh penelitian Kurniawan (2013) yang menunjukkan bahwa 
pemberian MPASI kurang dari 6 bulan dan keyakinan ibu memiliki hubungan yang signifikan dengan praktik pemberian ASI eksklusif.

Keberhasilan ibu bekerja dalam memberikan ASI secara esklusif juga tak lepas dari dukungan instansi. Hasil penelitian ini menunjukkan bahwa sebagian besar responden (30 orang) menyatakan instansi dangat mendukung, tersedia ruang laktasi dan diberi kelonggaran waktu untuk memerah. Hal ini sesuai dengan Peraturan Pemerintah No. 33 Tahun 2012 tentang Pemberian ASI Eksklusif. Penelitian mendapatkan data bahwa 9 kantor tidak menyediakan ruang laktasi secara khusus namun menggunakan ruangan yang tidak dipakai sebagai ruang laktasi. Adapun sarana prasarana yang ada meliputi sirkulasi udara baik, cahaya baik, ada kursi dan meja. Sebagian ruangan memiliki kulkas untuk menyimpan ASI perah.

Ketentuan untuk kesediaan ruang ASI di tempat kerja telah diatur di dalam peraturan perundangan. Berdasarkan pasal 128 ayat 2 dan ayat 3 UU Kesehatan jo. Pasal 6 Permenkes nomor 15 tahun 2013 menyebutkan bahwa pengurus tempat kerja harus memberikan fasilitas menyusui dan memerah ASI untuk ibu pekerja. Fasilitas tersebut dapat berupa ruang ASI yang sesuai standar memenuhi persyaratan kesehatan paling sedikit meliputi: ada pintu yang dapat dikunci, ventilasi dan sirkulasi udara yang cukup, ukuran minimal $3 \times 4 \mathrm{~m}^{2}$ (dan atau menyesuaikan dengan jumlah pekerja yang menyusui), bebas potensi bahaya di tempat kerja termasuk polusi derta ada wastafel dengan air mengalir. Pengurus tempat kerja yang menghalangi program pemberian ASI eksklusif dapat mendapat sanksi yaitu dipidana penjara maksimal 1 tahun dan denda maksimal Rp 100 juta (Pasal 200 jo 201 UU Kesehatan).

Hasil penelitian Nkrumah (2017) menunjukkan bahwa tidak ada hubungan yang signifikan antara jarak rumah dengan tempat kerja serta lama bekerja dengan perilaku pemberian ASI eksklusif pada ibu bekerja. Ibu bekerja dapat tetap memberikan ASI eksklusif dengan cara tetap memerah ASI selama bekerja setiap dua jam dan ibu menyusui langsung pada bayinya saat berada di rumah. Pada penelitian ini seluruh instansi memberikan kelonggaran waktu bagi ibu bekerja untuk memerah di sela waktu kerja, waktu cuti yang diberikan selama 3 bulan. Beberapa instansi masih perlu ditingkatkan adanya fasilitas tempat khusus untuk menyusui sesuai dengan ketentuan kesehatan. 
Tabel 6. Analisis multivariat determinan yang mempengaruhi pemberian ASI eksklusif

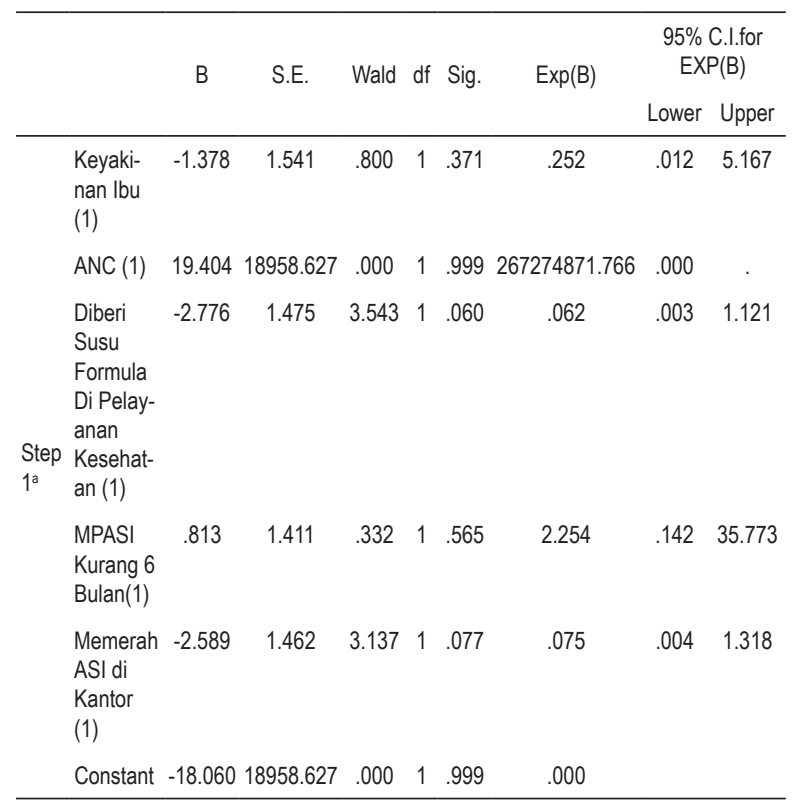

*Uji Regresi Logistik

Tabel 6 menunjukkan bahwa variabel yang berhubungan bermakna dengan praktik pemberian ASI tidak ada. Kelima variabel tersebut termasuk variabel confounding karena $\mathrm{p}$ value lebih dari 0,05 . Hasil analisis menunjukkan bahwa antenatal care memiliki Odss Ratio (OR) terbesar. Hal ini berarti antenatal care paling besar pengaruhnya terhadap praktik pemberian ASI secara eksklusif.

Hasil penelitian ini sejalan dengan penelitian Agho et.al (2011) yang menunjukkan bahwa faktor antenatal care merupakan determinan pemberian ASI eksklusif di
Nigeria. Ibu yang melakukan kunjungan antenatal selama empat kali atau lebih secara signifikan melakukan pemberian ASI eksklusif.

Ibu hamil diharapkan dapat meningkatkan pengetahuan tentang ASI eksklusif sehingga keberhasilan pemberian ASI eksklusif dapat tercapai. Tenaga kesehatan juga diharapkan dapat berperan aktif dalam memberikan edukasi selama perawatan antenatal tentang pemberian ASI eksklusif.

\section{KESIMPULAN DAN SARAN}

Simpulan dari penelitian ini adalah sebagian besar ibu bekerja (58,3\%) melakukan praktik pemberian ASI eksklusif, tidak ada hubungan antara karakter sosiodemografik dengan praktik pemberian ASI eksklusif, faktor pre dan post natal yang mempengaruhi praktik pemberian ASI eksklusif adalah ANC dengan $\mathrm{p}$ value 0,012 , faktor psikososial yang memiliki hubungan signifikan dengan praktik pemberian ASI antara lain pemberian susu formula di pelayanan kesehatan ( $\mathrm{p}$ value 0,003), pemberian MPASI saat usia kurang dari 6 bulan ( $\mathrm{p}$ value 0,032$)$, keyakinan ibu (p value 0,000$)$ serta antenatal care paling besar pengaruhnya terhadap praktik pemberian ASI secara eksklusif. 
Saran dari penelitian ini antara lain bagi pemerintah Kabupaten Klaten, diharapkan untuk menyusun kebijakan yang tegas untuk penyediaan fasilitas ruang menyusui bagi ibu bekerja yang sesuai dengan standar. Bagi instansi pemerintah Kabupaten Klaten, diharapkan untuk memberikan dukungan pada ibu menyusui terutama penyediaan sarana prasarana serta bahan bacaan. Bagi perawat, diharapkan untuk selalu melakukan promosi kesehatan dengan berbagai metode dan media untuk menggalakkan ASI eksklusif pada ibu bekerja. Bagi peneliti selanjutnya, diharapkan untuk melakukan penelitian lain dengan jumlah sampel yang lebih besar serta desain yang berbeda seperti metode kualitatif ataupun intervensi.

\section{DAFTAR PUSTAKA}

\section{Jurnal:}

Agho KE, Dibley MJ, Odiase JI, Obgonmwan SM. 2011. Determinants of exclusive breastfeeding in Nigeria. BMC Pregnancy and Childbirth, Vol 11, No 2. https://doi.org/10.1186/14712393-11-2

Astuti I. 2013. Determinan Pemberian ASI Eksklusif pada Ibu Menyusui. Jurnal Health Quality Vol 4 No.1:60-68

Kurniawan B. 2013. Determinan Keberhasilan Pemberian Air Susu Ibu Eksklusif. Jurnal Kedokteran Brawijaya, Vol. 27, No 4: 236-240

Nkrumah J. 2017. Maternal Work and Exclusive Breastfeeding Practice: A Community Based Cross-sectional Study in Efutu Municipal, Ghana. International Breastfeeding Journal Vol 12:10. DOI 10.1186/s13006-017-0100-6

Suan MAM, Ayob A, Rodzali M. 2017. Childcare workers' experiences of supporting exclusive breastfeeding in Kuala Muda District, Malaysia: a qualitative study. International Breastfeeding Journal 12:2. DOI 10.1186/s13006-016-0095-4 
ISSN: 1858-3385, EISSN: 2549-7006

GASTER Vol. 17 No. 2 Agustus 2019

\section{Buku}

Depkes. 2012. Peraturan Pemerintah Tentang Pemberian ASI Eksklusif No. 33 Tahun 2012.

Kementerian Kesehatan Republik Indonesia. 2013. Pedoman Pelaksanaan Stimulasi, Deteksi dan Intervensi Dini Tumbuh Kembang Anak Ditingkat Pelayanan Kesehatan Dasar. Kementerian Kesehatan Republik Indonesia.

Kristiyanasari W. 2009. ASI, Menyusui dam Sadari. Yogyakarta: NuhaMedika

Peraturan Daerah Kabupaten Klaten Nomor 7 Tahun 2008 tentang Inisiasi Menyusui Dini dan Air Susu Ibu Eksklusif

Peraturan Menteri Kesehatan Nomor 15 Tahun 2013 tentang Tata Cara Penyediaan Fasilitas Khusus Menyusui dan/atau Memerah Air Susu Ibu

Prasetyono. 2012. Buku Pintar ASI Eksklusif. Yogyakarta : Diva Press

Roesli. 2008. Panduan Inisiasi Menyusui Dini. Jakarta: Pustaka Bunda

Undang-Undang RI Nomor 36 Tahun 2003 tentang Kesehatan.

WHO. 2009. Infant and Young Child Feeding: Model Chapter for textbooks for medical students and allied health professionals. Genewa: WHO

\section{Informasi dari Internet:}

Riskesdas . 2013. Badan Penelitian dan Pengembangan Kesehatan. Jakarta. http://www.depkes. go.id/resources/download/general/Hasil\%20Riskesdas\%202013.pdf (5 Maret 2018)

WHO, UNICEF. 2003. Global Strategy for Infant and Young Child Feeding. Geneva: WHO. http://apps.who.int/iris/bitstream/10665/42590/1/9241562218.pdf . (5 Maret 2018)

WHO. 2017. Guideline: protecting, promoting and supporting breastfeeding in facilities providing maternity and newborn service. http://apps.who.int/iris. (5 Maret 2018) 